解 説

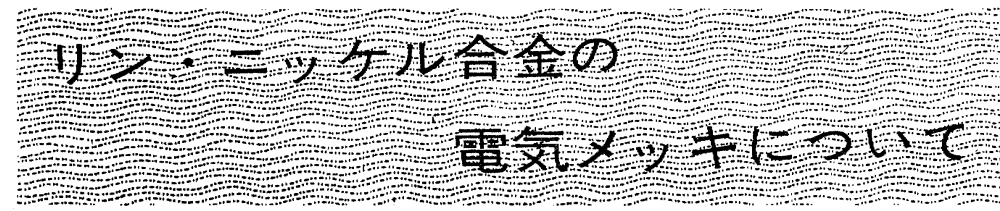

星 野 芳 明

従来, 硬質電気メッキ法としては, クロムメッキのみであったが, 最近,リン ニッケル合金メッキが硬質メッキ部門で実用化できるようになってきた.

そこで，実用化されつつある，リン $6 \%$ 前後, ニッヶル $94 \%$ 前後のメッキ 皮膜のもつカタサ, 酎摩耗性，耐食性など，物性について，できるだけ現場 的な観点から調べてみた。

さらに，このメッキ浴の液管理や作業性について，抒よび用途や将来性に ついても考察してみた.

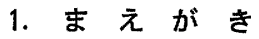

リン・ニッケル合金皮膜を電気メッキ法で 得ることは, 古く1950年頃, Brenner らによ って発表されている1)，このときのリン・ニ ッケル合金メッキは実験室的に得られたのみ で,メッキ作業条件すなわち，浴温度，液の $\mathrm{pH}$, 電流密度などの変化によって, 著しくメ ッキ皮膜中のリンとニッケルの組成比が変わ ってしまい，工業化できない状態であった。

今までに工業化されているリン・ニッケル 合金メッキ法は，いわゆるカニゼン法式とい われている次亜リン酸塩を還元剤とする無電 解メッキ法であった。 しかし，この方法は電 氮メッキと異なり，処理液を半永久的飞使用 することが困難であり，したがって，コスト 面特よび排水処理面に招いて，一般工業用厚 付けメッキにはむかず，特殊部品に限定され ていた.

ところが，最近になって工業的に使用でき るリン・ニッケル合金の電気メッキ法が商品
化されだしたので，この皮膜の物性を硬質ク ロムメッキと比較しつつ, 工業用メッキとし ての将来性を考えてみたいと思う。

\section{2. 電解による合金メッキはどの程度み つけられているか}

リン・ニッケル合金を含め, 合金メッキは かなり古くから開発されて特り, 黄銅メッキ は，すでに1841年に現在と同じ方法で工業的 に行なわれていた.

A. Krohn らの交献 “Electrodeposition of Alloysー1965 to 1970”によると，1960年ま でに 113 種，1961～1970年までに72種の 2 元 合金が発表されている2（文献2)の図は本紙 に載せられないので省略).

しかしながら，液管理の困難さ，析出合金 組成の不安定さなど, 量産性が悪く, 現在, 工業化されている種類は少ない.

合金メッキは単一金属のメッキに比べ, 多 くの利点を有している. 一般に, 合金メッキ は硬く，耐食性にすぐれて和り，有孔性が少 
なく，外観も美しい，また，その合金組成を 変えることにより，種々の特性を選定するこ とができる.

たとえば, リン・ニッケル合金メッキの場 合, 電解, 無電解いずれの方法からも得られ るが，その物性は注とえど同様で，析出合金 組成さえ安定していれば，高いカタサ，すぐ れた耐摩耗性, 耐食性が大いに期待し得るも のである.

\section{3. 電解リン・ニッケル合金メッキ浴と その作業性について}

電気メッキ浴としては，前記に述べたよう に, 1950年頃発表された Brenner 浴に端を 発し, 表 1 に示すような市販品もいくつか発 表されている.

その作業工程は，一般的に普通のニッケル メッキと同様と考えて差しつかえない.

また，均一電着性および被覆力を含めた， いわゆる，ッキマワリや排水処理問題につい ても, やはり普通のニッケルメッキと同様, もしくは幾分すぐれていると考えてよいだる 5 .
さて次に，硬質クロムに変わり，まるいは 非鉄素材の硬化処理として工業化されている 市販品を取りあげて，そのメッキ浴から得ら れる, リン $6 \%$ 前後, ニッケル $94 \%$ 前後のメ ッキ皮膜の物性についてまとめてみよう.

\section{4. リン・ニッケル合金の物性について}

\section{4-1 カタサについて}

一般に, ッキした金属のカタサは, 溶解, 鋳造して圧延したるのより高い（図 1). そ れは, 水素や添加剂の吸蔵, 異物の混入により 金属の結晶格子にヒズミが生じ，それに基づ 〈内部応力が発生するためと考えられる ${ }^{3}$.

リン・ニッケル合金析出物が熱処理される ことによって硬化現象を示すことはよく知ら れており，その硬化現象の機構については, 熱処理されることによってリンが $\mathrm{Ni}_{2} \mathrm{P}$, $\mathrm{Ni}_{3} \mathrm{P}$ などの 金属化合物をつくり，それが析 出構造にヒズミを与え, カタサを高くしてい ると考えられる.

(a) 熱処理温度とカタサの関係

熱処理の方法には, 電気炉 (ふ九好気とし て空気中または真空中，あるい性不活性ガス

表 1 リン・ニッケル合金のメッキ浴

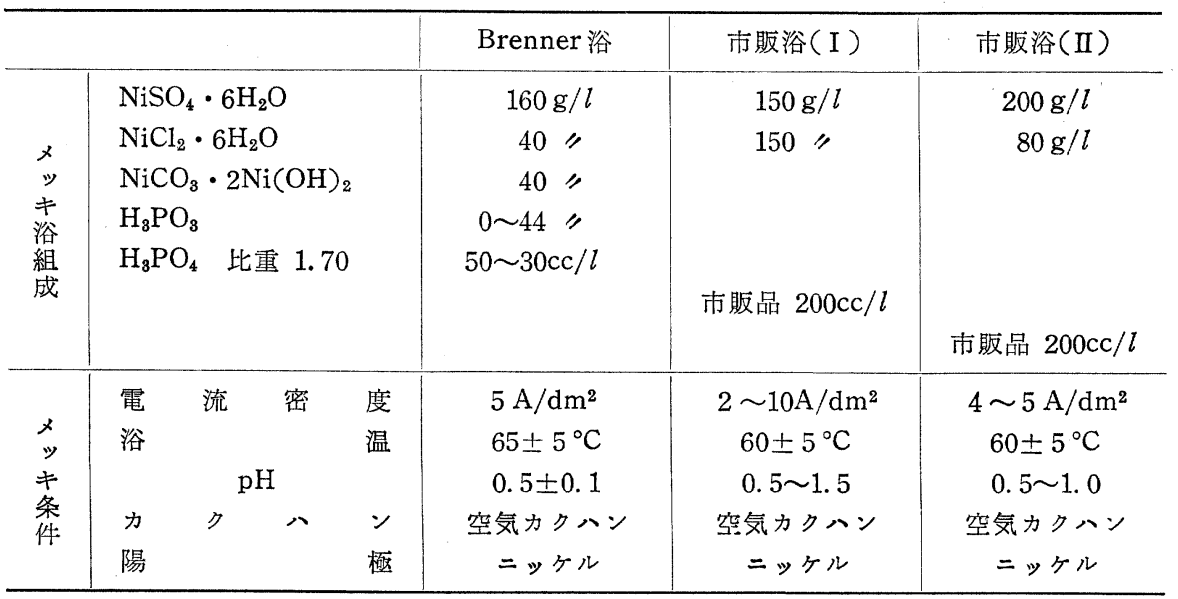




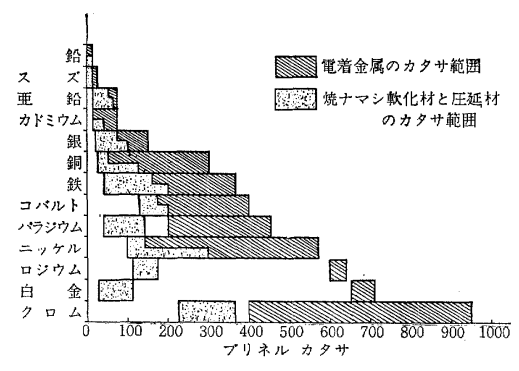

図 1 電着金属のカタサ

中), オイルバス炉，塩浴炉，低融点金属浴炉 など,設備的に多種あるが，もっとも簡単で, 一般的な空気中で熱処理した場合について, 処理時間を 1 時間と一定にして温度とカタサ の関係を調べてみた（図2）.

図 2からみられるように，比較の意味で載 せた硬質クロムメッキ皮膜とはかなり違った 傾向を示す.リン・ニッケル合金析出物は, $400^{\circ} \mathrm{C}$ 位まで温度の上昇と共にカタサが高く なる、たと壳ば、メッキ後のバフ研摩でも摩 擦熱のためにカタサは上昇する. しかし，こ の皮膜の唯一の欠点は, 後述するが, $400^{\circ} \mathrm{C}$ 以上の高温下での使用に耐えない。

(b) 熱処理温度之時間の関係

処理時間一定に打引る処理温度とカタサの 関係を示したが，硬化処理にあたって処理温 度と処理時間との関係を明らかにして和く必 要がある.そこでまず, 熱処理温度を $250^{\circ} \mathrm{C}$, $300,350, お$ おび $400^{\circ} \mathrm{C}$ と変えて処理時間と カタサの関係を調べてタた（図3）.

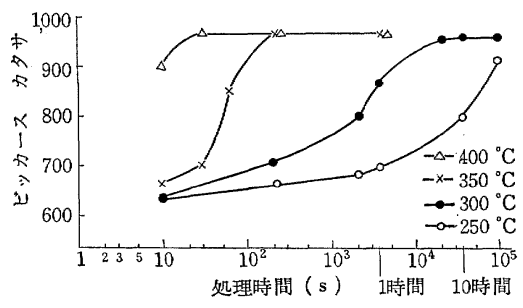

図 3 各温度に括ける熱処理時間と カタサとの関係

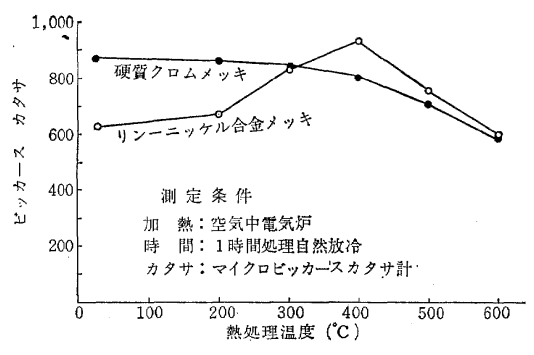

図 2 処理時間一定に括け告熱処理 温度とカタサとの関係

図 3 から $400^{\circ} \mathrm{C}$ ま゙の範囲で, 平衡時の最 高カタサは, $250^{\circ} \mathrm{C}$ 位の低い温度でも， $400^{\circ} \mathrm{C}$ と同じ高い值を示すことがわかる，ただ，処 理温度によって平衡カタサに到達するまでの 時間がかなり違う.そこで, 処理温度と処理 時間との関係をみてみると, 图4のよらに処 理時間の対数と処理温度との間にほぼ直線関 係が成り立つ（文献）にも同様な傾向あり）.

(c) 高温下のカタサ

$350^{\circ} \mathrm{C}$ で硬化処理したるのと末硬化のもの とを用い, 加熱中のカタサの変化を高温カタ サ計で測定してみたところ，図５に示すよう にリン・ニッケル合金は $350^{\circ} \mathrm{C}$ を越えると, 急激にカタサが低下し，硬質クロムメッキよ り高温時では低い值を示す.

\section{4-2 耐摩耗性について}

耐摩耗性を左右する因子として, (1)摩擦材 料相互の凝着性, (2)酸化皮膜々の他の凝着阻 止力, (3)表面アラサと摩擦面相互のなじみや すさ, (4)材料の強度拉よびカタサ, などが考

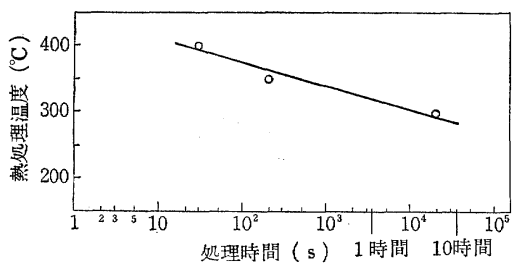

図 4 最高のカタサにたっするまでの 処理温度と処理時間との関係 
えられ，摩耗に耐えるか否かはケースバイケ ースで，実際にアッセンブリーして試験して みなければわからない。

しかし，耐摩耗性を評価する意味で，実際 との相関性は，はっきりわからないが，加速 的に見る一つの方法としてアムスラ一型摩耗 試験機を用いてテストしてみた. その結果の 1 部を示す（表 2 ）。

アムスラー型摩耗試験機は, 試験片のすり 合わせの良否によってその試験値に差異を生 じやすく，したがって，再現性に乏しいが， 本試験の数值から次の傾向がうかがわれる.

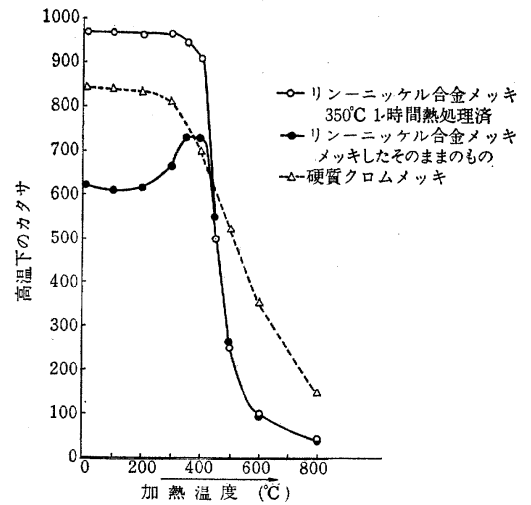

図 5 高温下のカタサ

表 2 摩 耗 試 験の結果

\begin{tabular}{|c|c|c|c|c|c|c|}
\hline \multirow{2}{*}{$\begin{array}{cc} & \text { 試 } \\
\text { 固 定 }\end{array}$} & \multicolumn{3}{|l|}{ 片 } & \multicolumn{2}{|c|}{ 摩耗減量 (mg) } & \multirow{2}{*}{$\begin{array}{l}\text { 估 事 量 } \\
(\mathrm{kg} \cdot \mathrm{m} / \mathrm{h})\end{array}$} \\
\hline & 回 転 & 子 & & 固定子 & 回転子 & \\
\hline \multirow{4}{*}{$\begin{array}{c}\text { 砲 金（軸受用材） } \\
\text { カタサ Hv } 132\end{array}$} & $\mathrm{Ni} \cdot \mathrm{P}\left(200^{\circ} \mathrm{C}\right)$ & & 685 & 2.6 & 16.3 & 794 \\
\hline & $"\left(400^{\circ} \mathrm{C}\right)$ & " & 823 & 4.8 & 12.7 & 560 \\
\hline & $"\left(600^{\circ} \mathrm{C}\right)$ & $"$ & 542 & 2.1 & 5.4 & 276 \\
\hline & クロム & $"$ & 950 & 6.0 & 3.7 & 546 \\
\hline \multirow{4}{*}{$\begin{array}{l}\text { ステン レ ス 鋼 } \\
\text { (SUS 27) } \\
\text { カタサ } \mathrm{HV} 500\end{array}$} & $\mathrm{Ni} \cdot \mathrm{P}\left(200^{\circ} \mathrm{C}\right)$ & $\mathrm{Hv}$ & 685 & 0.6 & 19. 0 & 525 \\
\hline & $=\left(400^{\circ} \mathrm{C}\right)$ & $"$ & 823 & 1. 2 & 7.9 & 301 \\
\hline & $"\left(600^{\circ} \mathrm{C}\right)$ & " & 542 & 0 & 7.9 & 190 \\
\hline & クロム & " & 950 & 0.9 & 1.5 & 1,685 \\
\hline \multirow{2}{*}{$\mathrm{Ni} \cdot \mathrm{P}\left(400^{\circ} \mathrm{C}\right)$} & $\mathrm{Ni} \cdot \mathrm{P}\left(200^{\circ} \mathrm{C}\right)$ & $\mathrm{Hv}$ & 685 & 3.1 & 6.1 & 1,345 \\
\hline & $" \quad\left(400^{\circ} \mathrm{C}\right)$ & " & 823 & 0.7 & 6.4 & 264 \\
\hline カタサ $\mathrm{Hv} 685$ & $"\left(600^{\circ} \mathrm{C}\right)$ & " & 542 & 1.6 & 1. 0 & 285 \\
\hline \multirow{2}{*}{$\mathrm{Ni} \cdot \mathrm{P}\left(400^{\circ} \mathrm{C}\right)$} & $\mathrm{Ni} \cdot \mathrm{P}\left(200^{\circ} \mathrm{C}\right)$ & $\mathrm{Hv}$ & 685 & 1.9 & 2.5 & 572 \\
\hline & $"\left(400^{\circ} \mathrm{C}\right)$ & $"$ & 823 & 2.1 & 1.2 & 265 \\
\hline カタサ $\mathrm{Hv} 823$ & $"\left(600^{\circ} \mathrm{C}\right)$ & $"$ & 542 & 2.9 & 1.0 & 252 \\
\hline \multirow{2}{*}{$\mathrm{Ni} \cdot \mathrm{P}\left(600^{\circ} \mathrm{C}\right)$} & $\mathrm{Ni} \cdot \mathrm{P}\left(200^{\circ} \mathrm{C}\right)$ & $\mathrm{Hv}$ & 685 & 0 & 3.6 & 1,700 \\
\hline & $"\left(400^{\circ} \mathrm{C}\right)$ & " & 823 & 1.5 & 10.5 & 419 \\
\hline カタサ $\mathrm{Hv} 542$ & $"\left(600^{\circ} \mathrm{C}\right)$ & $"$ & 542 & 0.2 & . 1.0 & 125 \\
\hline \multicolumn{2}{|c|}{$\begin{array}{l}\text { ただし, 表中 } \mathrm{Ni} \cdot \mathrm{P}\left(200^{\circ} \mathrm{C}\right) \mathrm{Hv} 685 \text { とは, } \\
\text { リン・ニッケル合金 }\end{array}$} & \multicolumn{5}{|c|}{ 30番モーヒヒル油連続滴下 } \\
\hline \multicolumn{2}{|c|}{ 熱処理 $200^{\circ} \mathrm{C}$ ，ビッカース，カタサ 685} & & $7 z=$ & 試験機, & & 定子 \\
\hline
\end{tabular}


(i ) リン・ニッケル合金メッキ回転子の 摩耗量は, 高い温度で熱処理したもの汪 ど少なく, その仕事量 (摩擦係数に比例 する）も同じ傾向を示す.

(ii） $600^{\circ} \mathrm{C}$ の温度で熱処理したリン・ニ ッケル合金の摩擦係数は硬質クロムメッ キより低い.

(iii) リン・ニッケル合金メッキ同士を組 合わせる場合には，固定子より熱処理温 度が高いか，あるいは等しい回転子の組 合わせが好ましい.

\section{4-3 耐食性について}

メッキ製品の防食機構を考える場合，次の 二つに大別できると思う.

（i）メッキ皮膜と素材, あるいはメッキ 層間の電位差を利用した局部電池作用に 基づく防食—ータン（亜鉛メッキ）, 装 飾メッキなど

（ii）メッキ皮膜のもつ耐薬品性に基つくく 防食一ブリキ(スズメッキ)，貴金属 メッキなど

実際, 数ミクロンから10数ミクロン前後の
メッキ製品の場合，ピンホールなど，メッキ 表面欠陷を皆無にすることはむずかしい，し たがって，赤サビ発生を防ぐことだけ考劣れ ば，鉄素地上の亜鉛メッキのようなるのがよ い.しかし，用途範囲を広げるためには，耐 薬品性のよい, かつ, メッキ時の表面欠陥(ピ ンホールなど) の少ないメッキを選択するこ とが必要になる，適切なリン・ニッケル合金 メッキは，まさにこれに該当するものと考学 てよい.

現在, 硬質クロムメッキの加速腐食試験と して，一般的に塩水噴霧試験が行なわれてい るようである. そこで, リン・ニッケル合金 メッキ製品について，塩水噴霧試験，キャス 試験，亜硫酸ガス試験などを行なって，硬質 クロムと比較しつつ耐食性を調べてみた（表 3).

表 3 からリン・ニッケル合金は，すべてに おいて硬質クロムよりはるかに耐食性が良好 である.な唁考として、リン・ニッケル合 金自体の酎薬品性は文献)をみられるよ W.

表 3 加速試験飞よる耐 食性

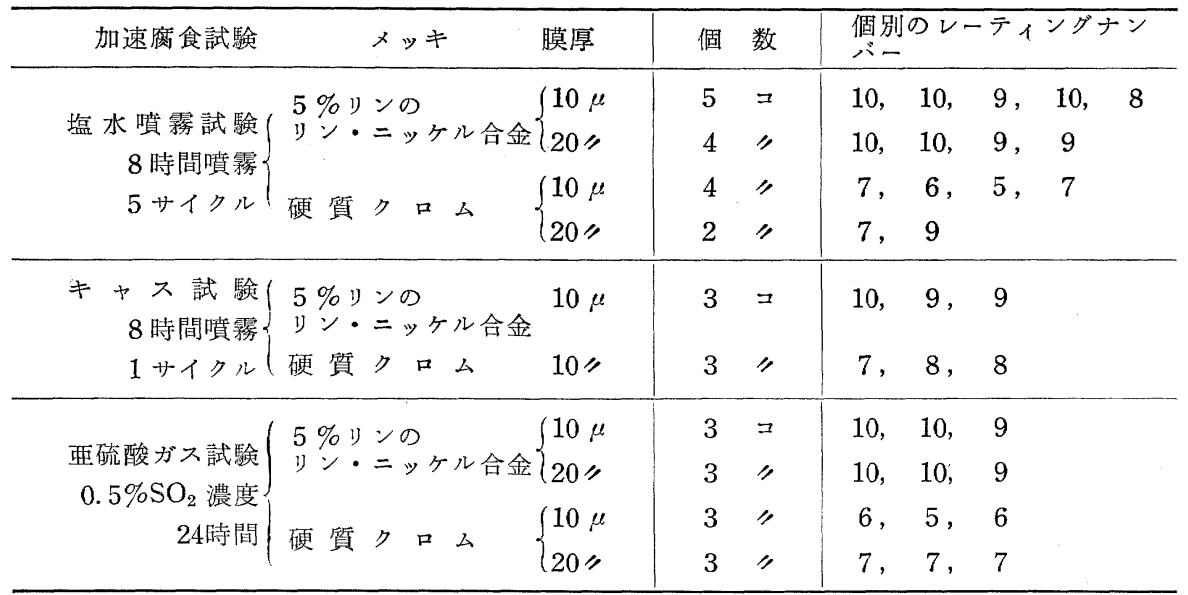

ただし，各試験とすレーティングナンバーが大きい汪ど耐食性が良い． 試験品は鉄素材のピストンロッドを用いた 
クロム金属と比較してみると，クロム金属 は, 塩酸, 硫酸に浴解するが, 硝酸, 王水な ど, 酸化性が強いと不動態化するのに対し, リン・ニッケル合金屰で，硝酸，王水，ク ロム酸など酸化性が強いものには不適当であ る.

また，熱処理と耐食性の関係について，文 献5)から熱処理した方が酎薬品性がよいよう なので，メッキ製品の耐食性も適切な熱処理 条件（たとえば熱処理によりキ裂が生じな い)であれば，向上しても低下することはな いと考えられる.

\section{5. 用 途亡将来 性}

以上，述べてきたことの総合的傾向を示す 意味で比較表（表 4 ）を作成してみたので, 参考にしていただきたい。

以上述べてきたように，リン・ニッケル合
金は, ニッケル93〜95\%, リン 7〜5\%の組 成をもつ妇のに限定した。 その理由は，厚付 讨性や合金皮膜の安定性など作業管理におい て，硬質メッキ加工部門にもっとも適してい ると考えたためである、な牧現在，ピストン ロッド，軸受，その他，機械部品に実績を得 つつある。

\section{6. お わりに}

今後, 経済社会の発達にともなって, カタ サ，耐摩耗性，耐食性を必要とする部品が益 々らえるだろうし，種々の材質が取り入れら れる中で，普通のニッケルメッキと同様な作 業方法で量産でさるということは，大いにメ リットがあり，かつ，役立つと考えられる。

\section{参 考 文 献}

1) A. Brenner, D. E. Couch \& E. K. Williams

表 4 性 能比較 表

\begin{tabular}{|c|c|c|c|c|}
\hline & 性 能 項 目 & $5 \%$ 5 ソの・Ni合金 & 硬質クロム & 光沢ニッケル \\
\hline \multirow{3}{*}{ 皮 } & \multirow{2}{*}{ カタサ $\left\{\begin{array}{l}\text { メッ上がり } \\
300^{\circ} \mathrm{C} \text { 処理 }\end{array}\right.$} & \multirow{2}{*}{$\begin{array}{l}\text { Hv } 600 \sim 700 \\
" \quad 800 \sim 900\end{array}$} & \multirow{2}{*}{$\begin{array}{l}\text { Hv } 800 \sim 900 \\
\text { " } \quad 750 \sim 850\end{array}$} & \multirow[t]{2}{*}{$\mathrm{Hv} 400$ 位 } \\
\hline & & & & \\
\hline & (塩 酸 & 良 & 悪 & 不 \\
\hline \multirow{3}{*}{ 膜 } & 耐薬品性 $\{$ 硫 酸 & 良 & 不 & 不 \\
\hline & (硝 酸 & 良 & 優 & 最 \\
\hline & (塩水噴霧 & 優 & 良 & 良 \\
\hline \multirow{2}{*}{ の } & 耐食性 $\{\neq$ ス & 良 & & 不 \\
\hline & $\mathrm{SO}_{2}$ ガス & 良 & 最 & 最 \\
\hline \multirow{3}{*}{ 物 } & 耐 摩 耗 性 & 良 & 優 & 不 \\
\hline & 重 & 8.0 & 7.2 & 8.9 \\
\hline & 度 & $890^{\circ} \mathrm{C}$ & $1,890^{\circ} \mathrm{C}$ & $1,455^{\circ} \mathrm{C}$ \\
\hline \multirow{3}{*}{ 性 } & 線 膨 張 係 数 & $13 \times 10^{-6} /{ }^{\circ} \mathrm{C}$ & $6.2 \times 10^{-6} /{ }^{\circ} \mathrm{C}$ & $13.3 \times 10^{-6} /{ }^{\circ} \mathrm{C}$ \\
\hline & 熱 伝 導 度 & $0.105 \sim 0.135$ & $0.16 \mathrm{cal} / \mathrm{cm} \cdot \mathrm{s}{ }^{\circ} \mathrm{C}$ & $0.22 \mathrm{cal} / \mathrm{cm} \cdot \mathrm{s}{ }^{\circ} \mathrm{C}$ \\
\hline & 電 気 抵 抗 & $30 \times 10^{-6} \Omega \cdot \mathrm{cm}$ & 13. $0 \times 10^{-6} \Omega \cdot \mathrm{cm}$ & $6.58 \times 10^{-6} \Omega \cdot \mathrm{cm}$ \\
\hline \multirow{4}{*}{$\begin{array}{l}\text { 作液 } \\
\text { 業管 } \\
\text { 性理 }\end{array}$} & 均一電 着 性 & 良 & 最 & 良 \\
\hline & 陰 極 効 率 & $50 \%$ & $15 \sim 18 \%$ & $90 \%$ \\
\hline & 析 出 速 度 & $1 \mu / \mathrm{min} \cdot 10 \mathrm{~A} / \mathrm{dm}^{2}$ & $0.25 \mu / \mathrm{min} \cdot 20 \mathrm{~A} / \mathrm{dm}^{2}$ & $0.9 \mu / \mathrm{min} \cdot 5 \mathrm{~A} / \mathrm{dm}^{2}$ \\
\hline & 液管理の難易 & 容易 & & 容易 \\
\hline
\end{tabular}


J; Research N. B.S, Vo1. 44, p.109 (1950) 2) A. Krohn \& C. W. Bohn; Plating, March, p.237 (1971) 3) R.Weil "The Origins of Stress in Electrodeposits", Plating, February, p. 137 （1971）4）国立機関技術開発研究事業成果普及発表
会テキスト 昭和 46 年 3 月，工業技術院製科研 5） 日本カニゼン(株) “カニゼン耐食表”

ほしのよしおき 日本化学機材(株) 研究員 東京 都中央区日本橋小舟町 $2-7$

\section{第 49 回学術講演大会}

期 日 昭和 49 年 5 月 $22 \cdot 23 ・ 24$ 日（水・木・金）ただし，24日は見学会

場 所 サンケイ会館（東京都千代田区大手町 1-7-2 Tel. 東京 (03) 231-7171) 研究発表募集については Vol.25，No.1 を参照してください.

又, 参加申込について詳細等はVol.25，No. 4 に掲載いたします.

\section{第13回金属表面技術総合展示会（ME T SHOW）出品募集}

$$
\text { テーマ：自然と人間と表面技術 }
$$

期 日 昭和 49 年 5 月 19 日 23日 (日〜木) 5 日間

場所東京都立産業会館 ( $1 \cdot 2 \cdot 3$ 階全フロア)

東京都千代田区大手町 $1-2$ Tel. 東京 (03) 231-2561 9

時間 $10: 00 〜 16: 30$ (ただし，19日のみ $11: 00 〜 16: 30$ の予定）

入 場 自由 (無料)

出品申达方法”案内書拈よび申込書は本会にご連絡下されば送付いたします。 本会所定の申込書に記入のら光，和申し込み下さい. な执，小間料金は申込書と同時に申し受けます。

出 品 料 $\mathrm{A} \cdots 1.82 \mathrm{~m}$ (間口) $\times 1.21 \mathrm{~m}$ (奥行) 1 コマ 75,000 月

B …1.82m(間口) $\times 1.82 \mathrm{~m}$ (奥行) 1 コマ 85,000 円

出品申达締切昭和 49 年 3 月 20 日 (水)

一般展示最近の日本执よび海外飞抢壮る金属表面技術に関する素材, 設備, 機械, 薬品 など。な和公害防止コーナーを設ける予定。

特 別 展 示 スポーツと表面技術.

技 術相談金属表面技術に関する質問に応じなす。

書 籍販 売所関係出版社 100 余社の協力を得て, 国内の表面技術に関する書籍, 便覧, 辞典 類を一堂に集め展示, 即売します.

相互協賛：米国表面処理機械展
日時，昭和 49 年 5 月 20 日 25日
10 時 17 時
場所 USトレードセンター

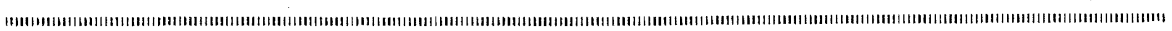

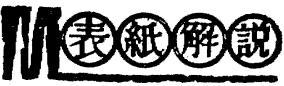

新 製 品

\section{硫酸銅メッキ用塩素測定器}

近年光沢硫酸銅メッキが多数使われるよう になってきましたか，この中で重要な塩素の 測定が潘とんど行なわれていませんでした。 この塩素測定器は硫酸銅メッキ液中の塩素イ オンが簡単正確に測定出来すす.

\section{測定方法}

1. メッキ液 200cc 採り活性宸を加光光沢剤
を沪過し除去する.

2. 沪液にA执よびB液を加え測定管に入れ セットする.

3. 30 分静置後測定器のランプをつけ測定管 の下部のコックをゆるめ液を出し, フィラ メントの形がわかった点で測定管を取り出 し，その目盛を読む。 それがメッキ液 $1 \ell$ 中の塩素イオンの量です.

価 格 測定器及び附属一式付 $¥ 48,000$

株式会社 山本 商 店 東京都渋谷区千駄ヶ谷 5 の 28 の 1 電話 東京 $352-2475$ (代) 